\title{
ANALYSIS OF THE EFFECT OF BRAND IMAGE, PRODUCT QUALITY AND AFTER- SALES SERVICE ON REPURCHASE DECISION OF SAMSUNG SMARTPHONES
}

\author{
Raditya Bayu* \\ Department of Business and Management, Faculty of School of Business, \\ Bogor Agricultural University, Bogor, Indonesia \\ Yuliati Lilik Noor, Krisnatuti Diah \\ Department of Economics, Faculty of Economy and Management, \\ Bogor Agricultural University, Bogor, Indonesia \\ *E-mail: bayu radith@yahoo.com
}

\begin{abstract}
International Data Corporation (IDC) stated that the market share of smart phones in Indonesia is very large with Samsung in the top rank. More and more smartphone brands in the Indonesian market causing smartphone companies to always improve the quality and innovate their products, especially for old brands so that their presence is maintained. The purpose of this study was to determine the respondent characteristics of Samsung smartphones in Special Capital Region of Jakarta, analyze the influence of brand image, product quality, after-sales service on repurchase decisions and formulate Samsung's managerial implications regarding strategies in maintaining Samsung smartphone consumer repeat purchase decisions. This study used a quantitative approach that is carried out by distributing questionnaires to respondents. Data is collected from November to December 2018. The respondents were determined by purposive sampling. Data processing techniques using SEM-PLS with SmartPLS M2.0 and descriptive analysis using Microsoft Excel. The results show that product quality and after-sales service have a significant influence on repurchase decisions, while brand image rejects the hypothesis, which has a positive but not significant effect. The managerial implication that Samsung can use as a manufacturer is to maintain the quality of durability and product reliability and provide special attention and comfort to smart phone users in accessing warranty claims on the products they have owned.
\end{abstract}

\section{KEY WORDS}

Brand image, repeat purchase decision, product quality, after-sales service, SEM-PLS.

International Data Corporation (IDC) stated that the smartphone market share in Indonesia is so large. Smartphone sales rose by as much as $17 \%$ or as much as 29.3 million units in 2016, so this sector is quite feasible to be worked on by both foreign and local companies. The development of the smartphone market in Indonesia shows that competition between companies both foreign and local compete to enter and create distinctive characteristics of their own strategies in getting consumers such as creating products and presenting new smartphone brands. The emergence of these new brands needs to be taken into consideration for brands that have long been in Indonesia so that their existence is maintained. The development of Indonesia's smartphone market share can be seen in Figure 1.

The existence of Samsung is still in the top rank in terms of smartphone market share achievements in Indonesia. This is certainly the strategies and policies implemented by Samsung itself. Product innovation continues to be carried out by Samsung smartphone brands to attract the attention of consumers, so consumers are willing to buy products that have been produced. Samsung's market share had experienced an increase in 2012-2013, but in 2014-2016 it had decreased. According to Hadi (2015), one of the things that made Samsung's sales declined due to the increasingly widespread smartphone brands from 
China such as Asus, Vivo, Oppo, Xiaomi, Huawei, Meizu, OnePlus (others) which took the segmentation of Samsung's middle-class smartphone market. The decline in Samsung's market share in 2016 was due to one of the best smartphone product outputs, the Samsung Galaxy Note 7, which product specifications were considered a failure because they could explode under certain conditions. The Samsung Galaxy Note 7 at its product launch received a very positive response from various circles, but because there was a production failure on the smartphone's battery, Samsung announced the decision to recall the Galaxy Note 7 from the world market on September $2^{\text {nd }} 2016$ which make some people (consumers) feel disappointed and threatened and switch their phones to other brand products.

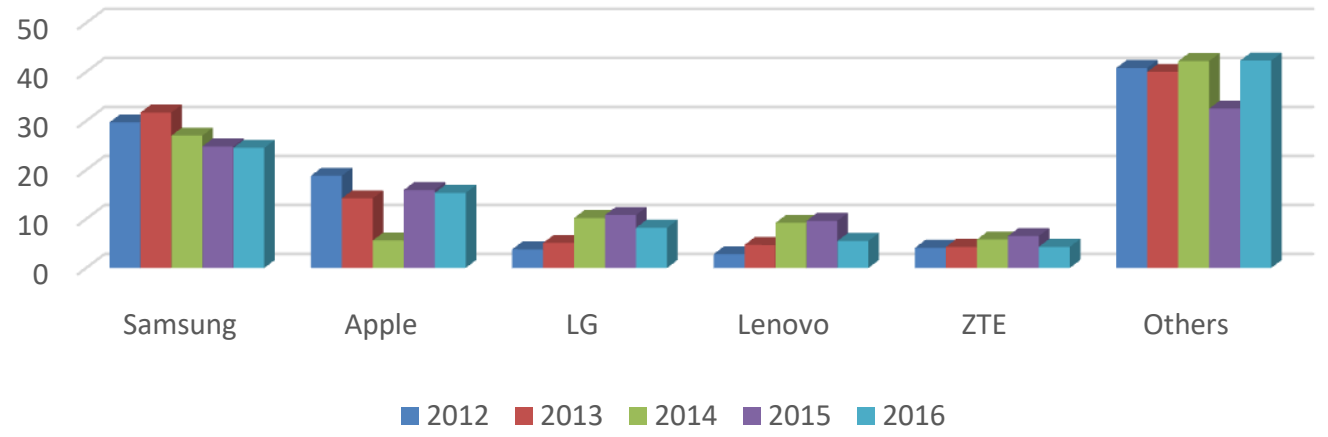

Figure 1 - The development of Indonesia's smartphone market share (Source: International Data Corporation, 2016)

The Samsung brand continues to strive to maintain the quality of its products so they don't lose the market potential to lose the market. Similar problems can also occur in other smartphone companies in Indonesia, so that the application of new innovations and improvements to the quality of important products continues to be carried out as a way to survive in the market with quite diverse competing products. Circulation of smartphones that are so diverse in the market with the types, shapes, specifications and brand names that exist, in the end consumers determine in making purchasing decisions. Consumers can be selective in choosing tastes, views, and beliefs in a brand that is believed to be good and suitable for purchase. Positive brand image is important in keeping consumers from moving to other brands.

Besides building a brand image, maintaining product quality is also an important thing. Product quality is things that are offered to the market to get attention, be bought, used or consumed that can satisfy consumer desires (Sundalangi et al. 2014). The better the quality of the product produced, the better chance for consumers to make purchasing decisions. The general purpose of establishing the quality of the product itself is to convince consumers that the product is the best according to consumer needs. Brand image and product quality can also make consumers make repurchase decisions on the products offered and increase market share. This is in line with the research of Devaraj et al. (2001) which states that good product quality can provide a good image of a product, thus creating a intention to re-buy from customers and Keller (2008) reveals that a quality product must be supported by a strong brand to become the market ruler.

Besides the formation of consumer preferences for brand and product quality, providing after-sales services to consumers can also increase consumer preferences in viewing products from preferred brands and product repurchase decision making. Boyd et al. (2000) said after-sales service is one dimension of consumer consideration in making purchasing decisions before dropping to choose products that suit their needs and desires. Smartphone companies even dare to provide after-sales services in the form of compensation if the product is not in good quality or not in accordance with the promotion delivered to convince consumers better. This is done to maintain consumer believe in the products that have been 
purchased, as well as to keep consumers from being able to repurchase and not move to other smartphone competitors.

Regarding after-sales service, some Samsung consumers still feel bad about the aftersales services provided by Samsung when viewed from handling unpleasant defects and the length of time to repair or replace parts that are not in accordance with the promised time as in LCD replacement cases (Junaidi 2016). These things caused many consumers complain about the after-sales services provided by Samsung. Based on the description of above regarding the phenomenon that occurred in the Samsung smartphone industry, the purpose of this study was to identify the respondent characteristics of Samsung smartphones in the DKI Jakarta area, analyze the influence of brand image, product quality, after-sales service on repurchase decisions Samsung smartphones in the Special Capital Region of Jakarta area and formulate strategic recommendations in maintaining the decision to repurchase Samsung smartphone users.

\section{LITERATURE REVIEW}

Brand image is an important thing for a company because the brand can reflect the manufacturer's quality of a good product or service. A brand image is a name, term, sign, symbol, design, or a combination of all that is intended to identify the seller's goods or services or a group of sellers and to differentiate them from competitor's goods or services (Kotler 2008). Rangkuti (2004) explains that brand image is a set of brand associations that are formed and embedded in the minds of consumers. Brand image is a representation of the overall perception of the brand that is formed through information and past experience of the brand itself (Setiadi 2003). According to Aaker and Biel (1993), Engel et al. (1995) and Simamora (2008) brand image has three components, namely:

- Corporate image, which is a set of associations that consumers perceive to companies that make products and services in a corporate network;

- User image, which is a set of associations that consumers perceive to users who use goods or services, including the user itself, lifestyle, personality, social status;

- Product image, which is a set of associations that consumers perceive to a product, which includes the product attributes, benefits for consumers, users, and guarantees.

Quality is the totality of the features and characteristics of a product or service that depends on its ability to satisfy expressed or implied needs (Kotler and Keller 2009). According to Kotler and Armstrong (2008) product quality is a product characteristic that depends on its ability to satisfy customer needs that are stated or implied. Iskandar (2015) explains that if the quality of the products produced is good, then consumers tend to make repeat purchases, while the quality is not in accordance with their expectation, consumers will change their purchases to other similar products, where consumers will buy products that they believe are higher quality. Every consumer must have a different perception of product quality, but consumers will choose products that can satisfy their needs. Quality reflects all dimensions of product offerings that produce benefits for customers (Tjiptono and Chandra 2012). According to Garvin (1987) and Tjiptono (2008) there are eight dimensions in product quality that need to be continuously considered and developed, those are:

- Product performance, related to the functional aspects of the product and the main characteristic (core product) that customers consider when they want to buy a product;

- Features, the second aspect of performance that adds basic functions, which is related to additional features;

- Reliability, related to the possibility of a product functioning successfully in a period of time and under certain conditions;

- Conformance, related to the level of conformity of the product to the specifications that have been previously set based on customer desires;

- Durability, a measure of the lifetime of a product. This characteristic is related to the durability of a product; 
- Serviceability (ease of repair), a characteristic related to speed, ease, and accuracy in repairs;

- Aesthetics, a characteristic of beauty that is subjective so that it is related to personal consideration and reflection or individual choice;

- Perceived quality, which is subjective, is related to customer feelings in consuming products, such as increasing self-esteem.

After-sales service is a service provided by producers to consumers after the consumer bought a product (Kotler and Keller 2009). According to Tjiptono (2008) there are several alternative strategies that can be done by companies to reduce the possibility of uncertainty by providing after-sales services, namely providing guarantees to reduce consumer perceptions of the risk of purchasing, repair services, and providing replacement parts. According to Levit, quoted by Tjiptono (2008), stated that the more sophisticated the technology of a generic product such as a car, a photocopy machine, a computer, the sales will depend on the quality and provision of accompanying customer services such as show rooms, delivery, repair and maintenance facilities, application assistance, operator training, installation consultation and warranty.

Budiarto and Tjiptono (2003) suggest that after-sales service is needed especially in relation to efforts to create customer satisfaction and repurchase. After-sales service measurements combine from several research journals namely Banerjee (2010), Angelova and Zekiri (2011), Fazlzadeh et al. (2011), Neha and Manoj (2013), Diyah et al. (2013), Kidane and Sharma (2016) and Khan et al. (2016). Based on these studies, the dimensions of after-sales service that can be applied to smartphone products are the provision of guarantees, information technology assistance through mobile phone applications and customer service.

The interest in repurchasing is basically the behavior of customers who respond positively to the quality of the services of a company if they meet consumer expectations or even exceed customer expectations, customers will intend to revisit or re-consume the company's products and customers will even convey good things to others (Kotler and Keller 2009). Repurchases occur if a product purchased with an experiment turns out to be satisfying or more satisfying than the previous brand, so consumers want to repurchase or repurchase shows purchases that occur after consumers have experience with products and companies (Schiffman et al. 1994). Repurchase behavior is often associated with loyalty. Evans and Laskin (1994) said in his research that loyal customers are people who make repeat purchases from similar companies, notify other potential customers through word of mouth and become an antidote to attacks from competitors. The interest in repurchasing can also be claimed as buying interest. Assael (1998) explains buying interest is a behavior that appears as a response to an object or is also an interest in repurchasing which shows the customer's desire to repurchase.

A positive image can be strength for the brand used by a product. The research conducted by Wijaya and Astuti (2018) found that brand image results have a positive and significant effect on consumer repurchase decisions, the better the brand image that can be created, the higher the decision to buy again from Berrybenka consumers in the Semarang region. Significant influence between brand image on purchasing decisions is also in line with research conducted by Huang et al. (2011), Ain and Ratnasari (2015) and Paramananda and Sukaatmadja (2018).

This indicates that the higher the brand image perceived by consumers, the higher the consumer's interest in repurchasing (Chen and Hsieh 2011). Ranjbarian et al. (2012) also stated that brand image indirectly affects repurchase decisions in Iranian department stores that are mediated by customer / consumer satisfaction. The decision to repurchase a product caused by the creation of a good brand image can help companies achieve good financial performance. This is consistent with the statement of Roberts and Dowling (2002) which states that the brand image of a company is valuable intangible capital that is difficult to imitate and can help the organization to achieve sustainable and superior financial performance. 
Previous research related to product quality on repeat purchase decisions is as follows: Kotler and Armstrong (2008) state that the better the quality of the products produced, the more opportunities for consumers to make purchasing decisions. Product quality is everything that is offered to the market to get attention, be bought, used or consumed that can satisfy consumer desires (Sundalangi et al. 2014). This is reinforced by the study of Lin and Lin (2007) which explains that product quality is the most important thing in purchasing decisions. Kurniawan et al. (2010), Lin et al. (2011), Isyanto (2012), Singh M (2013), Wulansari (2013), Sun et al. (2014), Iriani and Tunjungsari (2015) and Susanto (2016) state that product quality has a significant influence on consumer purchasing decisions and some of these studies product quality are among the most dominant factors in the decision to buy back a product by consumers.

Faradiba and Astuti (2013) also stated that product quality has a positive effect on repurchase decisions. Whereas from the research conducted by Bakator and Petrović (2016), product quality has a negative effect on product purchasing decisions and research from Yulisetiarini et al. (2011) states that product quality has no significant effect on consumer repurchase decisions. But research conducted by Dewi et al. (2015) sharpens the results of research that states the influence of product quality on repurchase decisions even with an intermediate variable. The study obtained results that state product quality indirectly affects consumers' repurchasing interest in fish products in the Semarang region with mediated purchasing decisions.

Previous research related to after-sales service for repeat purchase decisions is as follows: Boyd et al. (2000) say after-sales service is one dimension of consumer consideration in making purchasing decisions before dropping to choose products that suit their needs and desires. According to Levitt in Diyah et al. (2013) argue that product sales with the adoption of sophisticated technology depend on the quality of the product itself and the accompanying after-sales service. In buying a product, consumers expect all goods purchased can be followed by good after-sales service (Isaac et al. (2013). This indicates a significant influence between after-sales service on purchasing decisions, as expressed in Ruusen's research (2014), Saidin et al. (2015) and Kriswandari (2010). Besides that, Bayhaqi's (2006) research also emphasizes that service quality also has an indirect positive effect on consumers' buying interest with customer satisfaction as its mediating variable. Wijaya's (2019) research results confirmed the results obtained in the study of Ranjbarian et al., which states that after-sales services have a significant positive effect on repurchase intention through customer satisfaction, indicating that consumers' repurchasing interest can be improved through good after-sales service to produce high satisfaction in consumers.

\section{RESEARCH FRAMEWOK}

Based on the background and the description of the previous research, this study looks at how the influence of each independent variable namely brand image (X1), product quality (X2) and after-sales service (X3) on purchasing decisions (Y). For more details, we can see the relationship between independent variables and the dependent variable in Figure 2.

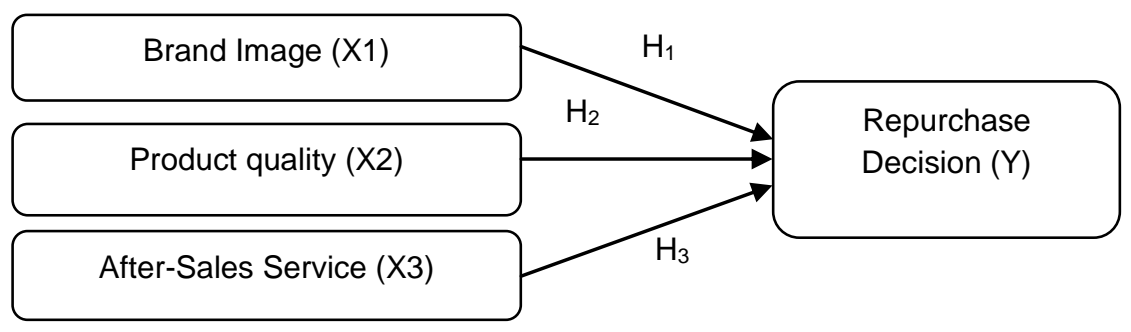

Figure 2 - Research Framework

Research hypothesis:

$\mathrm{H}_{1}$ : Brand Image has a positive effect on repurchase decision; 
$\mathrm{H}_{2}$ : Product quality has a positive effect on repurchase decision;

$\mathrm{H}_{3}$ : After-sales service has a positive effect on repurchase decision.

\section{METHODS OF RESEARCH}

The research to obtain data was carried out in November - December 2018 at Samsung service center outlets in the Special Region of Jakarta area (East Jakarta, North Jakarta, Central Jakarta, South Jakarta and West Jakarta).

This research is a quantitative description research conducted by the survey method approach. This survey method is carried out through the distribution of structured questionnaires to consumers or users of Samsung smartphone who are willing to be the respondents in this study. The questionnaire was given directly to respondents in Samsung service outlets located in Special Region of Jakarta area. Respondents are Samsung smartphone consumers or users and have done Samsung after-sales service at least once.

The data source in this study consisted of primary data and secondary data. Primary data obtained from the results of questions and statements of respondents through questionnaires. Questionnaires given to respondents contain closed types of questions (structured) so that respondents are limited in the space giving answers to alternative answers that have been provided. The answers to structured questions of respondents used the Likert scale (Summated Rating Scale). Likert scale is used to measure preferences, opinions and perceptions of a particular person or group of people about social events or symptoms, and besides that Likert scale is a psychometric scale that is commonly used in scale questionnaires which are most widely used in research in the form of surveys (Sugiyono 2012). Secondary data was obtained from the Annual report of Samsung, literature studies, articles, internet and other publications related to the research.

The sampling method is done by non-probability sampling techniques through a convenience sampling approach. Sumarwan et al. (2015) stated that non-probability sampling technique means that in determining the sample (example) no opportunity is needed so that the data generated only applies to people who are respondents to the study. Convenience sampling is chosen based on the consideration of the convenience of the researcher in getting the data he wants to obtain. According to Sugiarto et al. (2003) convenience sampling is sampling that is based on the availability of elements and the ease of obtain. Determination of the number of samples in this study amounted to 100 people which refers to the theory of Hair et al. (2006) that the use of data analysis methods Structural Equation Modeling (SEM) the minimum number of samples is 100 people, for models that contain five constructs or less, with each variable consisting of more than three observed variables and high communalities. Respondents in this study were consumers who used Samsung smartphones in the Special Region of Jakarta area. The criteria of respondents in this study were: 1) At the time of the interview, the respondents involved actively used Samsung smartphones, 2) Respondents had done after-sales service at Samsung's service center outlets.

Demographic variables are variables that can reflect or explain the characteristics of the respondents. In this study the demographic variables used were gender, age, education, type of work and level of expenditure per month. Independent and dependent variables, measurement dimensions and indicators and statements in this study are shown in Table 1.

Data processing in this study was carried out with several analyzes. The analysis in question includes Descriptive Analysis and analysis using Structural Equation ModelingPartial Least Square (SEM-PLS) which is processed using SmartPLS 2.0 Software. Descriptive analysis is intended to explain the demographic characteristics of respondents, while analysis using SEM-PLS is intended to explain the relationship between the variables studied. But before the data is processed and analyzed using SEM-PLS, validity test and level of consistency (reliability test) must be done on the questionnaire which is the measurement tool in this study. 
Table 1 - Variables and research dimensions

\begin{tabular}{|c|c|c|c|}
\hline Variables & Dimention & Indicators & Statement \\
\hline \multicolumn{4}{|r|}{ Exogenous Latent Variable } \\
\hline \multirow{7}{*}{$\begin{array}{l}\text { Brand Image } \\
\text { (X1) }\end{array}$} & \multirow{2}{*}{ Corporate Image } & $\mathrm{Cl} 1$ & Samsung smartphones are a memorable brand \\
\hline & & $\mathrm{Cl} 2$ & Samsung smartphones are well-known brand \\
\hline & \multirow[t]{2}{*}{ User Image } & Ul1 & Having a Samsung smartphone makes me proud \\
\hline & & UI2 & Samsung smartphones are brands that reflect high social status \\
\hline & \multirow{3}{*}{ Product Image } & PI1 & Samsung mobile phones have clear product characteristics \\
\hline & & $\mathrm{PI} 2$ & Samsung smartphone products give a positive impression on consumers \\
\hline & & $\mathrm{PI} 3$ & Samsung smartphones are easy to use \\
\hline \multirow[t]{19}{*}{$\begin{array}{l}\text { Product Quality } \\
\text { (X2) }\end{array}$} & Performance & $\begin{array}{l}\text { PF1 } \\
\text { PF2 }\end{array}$ & $\begin{array}{l}\text { Samsung smartphones have high-quality operating system performance } \\
\text { Samsung smartphones are equipped with the latest and sophisticated } \\
\text { features }\end{array}$ \\
\hline & \multirow[t]{3}{*}{ Features } & FT1 & Samsung smartphones are comfortable when used \\
\hline & & FT2 & The operation of the Samsung smartphone is relatively easy \\
\hline & & FT3 & Samsung smartphones have good camera resolution \\
\hline & \multirow[t]{2}{*}{ Realibility } & RL1 & Samsung smartphones have good quality in the hardware sector \\
\hline & & RL2 & Samsung smartphones have good quality in the software sector \\
\hline & \multirow[t]{2}{*}{ Durability } & DR1 & Samsung smartphones have long lifetime usage \\
\hline & & DR2 & Samsung smartphones have a long-lasting battery quality \\
\hline & \multirow[t]{2}{*}{ Aesthetics } & AS1 & Samsung smartphones have a unique design \\
\hline & & AS2 & Samsung smartphones have a variety of attractive colors \\
\hline & \multirow[t]{4}{*}{ Service ability } & SA1 & Samsung has the speed and accuracy in services \\
\hline & & SA2 & Completeness of spare parts availability \\
\hline & & SA3 & Friendly and fast service at Samsung Service Center \\
\hline & & SA4 & Samsung provides a call center that can be contacted at any time \\
\hline & \multirow[t]{3}{*}{ Perceived quality } & PQ1 & Samsung smartphones give a high self-image to users \\
\hline & & PQ3 & Samsung smartphones are good quality \\
\hline & & PQ4 & Samsung smartphones have specifications that consumers want \\
\hline & \multirow[t]{2}{*}{ Confronmance } & CF1 & $\begin{array}{l}\text { Samsung smartphones have good functional benefits such as for } \\
\text { telephones / sending short messages }\end{array}$ \\
\hline & & CF2 & $\begin{array}{l}\text { Samsung smartphones have benefits in accessing internet / email / } \\
\text { youtube / online games }\end{array}$ \\
\hline \multirow{7}{*}{$\begin{array}{l}\text { After-Sales } \\
\text { Service } \\
\text { (X3) }\end{array}$} & \multirow[t]{3}{*}{ Warranty } & GR1 & Samsung is fast and responsive to warranty claims \\
\hline & & GR2 & $\begin{array}{l}\text { Samsung can fulfill its promise of warranty claims in accordance with the } \\
\text { applicable terms and conditions }\end{array}$ \\
\hline & & GR3 & $\begin{array}{l}\text { Samsung makes it easy for consumers to access the repair and } \\
\text { compensation services }\end{array}$ \\
\hline & \multirow[t]{2}{*}{$\begin{array}{l}\text { Aplication } \\
\text { assistance }\end{array}$} & BA1 & $\begin{array}{l}\text { Samsung provides services in the form of an easy-to-use mobile phone } \\
\text { application }\end{array}$ \\
\hline & & BA2 & $\begin{array}{l}\text { Samsung smartphones have applications that can make it easier for } \\
\text { users to get the applications they need }\end{array}$ \\
\hline & \multirow[t]{3}{*}{ Customer service } & CS1 & Service center service is good \\
\hline & & CS2 & Samsung serves all customer needs \\
\hline \multicolumn{3}{|c|}{ Endogenous Latent Variable } & \\
\hline \multirow{3}{*}{\multicolumn{2}{|c|}{ Purchase Decision $(\mathrm{Y})$}} & KPU1 & I decided to re-buy a Samsung smartphone for the next purchase \\
\hline & & KPU2 & I will be loyal to using Samsung mobile phone products \\
\hline & & KPU3 & I will recommend Samsung smartphone products to others \\
\hline
\end{tabular}

\section{RESULTS AND DISCUSSION}

This study involved 100 respondents in accordance with predetermined characteristics, namely respondents as Samsung brand smartphone users and had done the brand aftersales service in the past year. Sampling of respondents (interviews) was carried out in several official Samsung outlets in the Special Region of Jakarta area. Demographic aspects of the respondents described in this study include gender, age, education level, type of work, and level of expenditure per month. Distribution of characteristics of respondents can be seen as complete in Table 2.

Samsung smartphone usage behavior referred in this study will further discuss the Samsung smartphone consumer's own behavior which includes the period of Samsung smartphone usage, reasons for respondents in Samsung smartphone selection, reasons respondents to continue to use Samsung smartphones and Samsung smartphone after-sales service user behavior. The behavior of Samsung smartphone users is more clearly seen in Table 3.

PLS is an alternative approach that shifts from a covariant SEM-based approach to a variant-based SEM (Ghozali 2006). SEM based on covariance generally tests causality while PLS is more predictive model. Jogiyanto and Willy (2009) stated that in modeling with 
prediction purposes, it can be done without a strong theoretical basis, and can ignore a number of (non-parametric) assumptions and the accuracy parameters of predictive models can be seen from the R-square. In forming the PLS model as a whole, we must first test the evaluation of the measurement model (outer model) by testing convergent validity, discriminant validity and composite reliability and evaluating structural models by looking at the R-square value for each endogenous latent variable, as predictive power from structural model.

Table 2 - Distribution of respondents based on the characteristics of respondents

\begin{tabular}{|c|c|c|c|c|c|}
\hline Charateristics & Catagories & $\begin{array}{l}\text { Respondents } \\
(\%)\end{array}$ & Charateristics & Catagories & $\begin{array}{l}\text { Respondents } \\
(\%)\end{array}$ \\
\hline Gender & Man & 52 & \multirow[t]{6}{*}{ Occupation } & Household Mothers & 17 \\
\hline & Women & 48 & & Students & 6 \\
\hline Total & & 100 & & State-owned enterprise & 8 \\
\hline \multirow{5}{*}{ Age } & \multirow{5}{*}{$\begin{array}{l}<20 \text { years } \\
20-30 \text { years } \\
31-40 \text { years } \\
41-50 \text { years } \\
>50 \text { years }\end{array}$} & 4 & & Private employees & 50 \\
\hline & & 47 & & Entrepreneur/ Professional & 15 \\
\hline & & 25 & & Others & 4 \\
\hline & & 20 & \multirow[t]{6}{*}{ Total } & & 100 \\
\hline & & 4 & & $\begin{array}{l}\text { IDR 1.000.001 - IDR } \\
2.000 .000\end{array}$ & 9 \\
\hline Total & & 100 & & $\begin{array}{l}\text { IDR 2.000.001 - IDR } \\
3.000 .000\end{array}$ & 23 \\
\hline \multirow[t]{4}{*}{ Education } & $\begin{array}{l}\text { High school/ } \\
\text { equivalent }\end{array}$ & 56 & & $\begin{array}{l}\text { IDR } 3.000 .001-\text { IDR } \\
4.000 .000\end{array}$ & 21 \\
\hline & Associate Degree & 12 & & $\begin{array}{l}\text { IDR } 4.000 .001 \text { - IDR } \\
5.000 .000\end{array}$ & 21 \\
\hline & Bachelor Degree & 27 & & IDR $>5.000 .000$ & 26 \\
\hline & $\begin{array}{l}\text { Post-graduate } \\
\text { Degree }\end{array}$ & 5 & \multirow[t]{2}{*}{ Total } & & 100 \\
\hline Total & & 100 & & & \\
\hline
\end{tabular}

Table 3 - Behavior of Samsung smartphone users

\begin{tabular}{|c|c|c|c|c|c|}
\hline Consumers Behavior & Categories & $\begin{array}{c}n \\
(\%)\end{array}$ & Consumers Behavior & Categories & $\begin{array}{c}n \\
(\%)\end{array}$ \\
\hline \multirow{4}{*}{$\begin{array}{l}\text { Number of Samsung smartphone } \\
\text { ownership }\end{array}$} & 1 piece & 43 & \multirow[t]{3}{*}{ Place to do the service } & Official Samsung store & 3 \\
\hline & 2 pieces & 37 & & $\begin{array}{l}\text { Samsung official } \\
\text { service center }\end{array}$ & 93 \\
\hline & 3 pieces & 10 & & $\begin{array}{l}\text { Common mobile phone } \\
\text { counters }\end{array}$ & 4 \\
\hline & $>3$ pieces & 10 & \multirow{5}{*}{$\begin{array}{l}\text { Total } \\
\text { Cost range for after-sales } \\
\text { services }\end{array}$} & & 100 \\
\hline Total & & 100 & & Free & 21 \\
\hline \multirow{5}{*}{$\begin{array}{l}\text { Alasan Pembelian smartphone Samsung } \\
\text { Reasons for Purchasing a Samsung } \\
\text { smartphone }\end{array}$} & Follow the trend & 9 & & $\begin{array}{l}\text { IDR } 50.001 \text { - IDR } \\
100.000\end{array}$ & 26 \\
\hline & Affordable prices & 15 & & $\begin{array}{l}\text { IDR } 100.001-\text { IDR } \\
200.000\end{array}$ & 17 \\
\hline & \multirow{3}{*}{$\begin{array}{l}\text { Good brand image } \\
\text { Samsung brand } \\
\text { popularity } \\
\text { Product } \\
\text { specifications }\end{array}$} & \multirow{2}{*}{$\begin{array}{l}13 \\
29\end{array}$} & & $>$ IDR 200.000 & 36 \\
\hline & & & Total & & 100 \\
\hline & & 34 & \multirow[t]{6}{*}{$\begin{array}{l}\text { Reasons for still choosing } \\
\text { Samsung smartphones }\end{array}$} & Product sophistication & 35 \\
\hline Total & & 100 & & $\begin{array}{l}\text { Product strength and } \\
\text { durability }\end{array}$ & 33 \\
\hline \multirow[t]{4}{*}{ Frequency of using after-sales services } & 1 time & 81 & & Ease of repairs & 15 \\
\hline & 2 times & 15 & & (service) & \\
\hline & 3 times & 3 & & Product display & 10 \\
\hline & $>3$ times & 1 & & Popular brand & 7 \\
\hline Total & & 100 & & Total & 100 \\
\hline Use of servive services other than & Never & 87 & & & \\
\hline Samsung official service center & Yes & 13 & & & \\
\hline Total & & 100 & & & \\
\hline
\end{tabular}

According to Hair et al. (2010) latent variables cannot be measured and observed directly, but are measured through one or more indicator variables. The size of the correlation between indicators and latent variables can be known through the calculation of load factors (loading factors):

- Convergent Validity; in this study, there is an outer loading value that shows a number $<0.7$ the calculation must be done several times until all indicators get the 
value of outer loading $\geq 0.7$ and can be seen in Figure 3 on the results of loading factors;

- Discriminant Validity; in the reflective measurement model the indicator is assessed based on the value of AVE (Average Variance Extracted), the value must be greater than 0.5 . The results of discriminant validity can be seen in Table 4;

- Composite Reliability; is a reliability test in PLS where the results show the level of accuracy, consistency of the accuracy of a tool (questionnaire) in making measurements. Composite reliability is considered good if it has a value of more than 0.7. Composite reliability can be seen in Table 4.

Table 4 - Discriminant validity and composite reliability test results

\begin{tabular}{lll|lll}
\hline Dimentions/indicators & AVE $(>0.5)$ & CR $(>0.7)$ & Dimentions/indicators & AVE $(>0.5)$ & CR $(>0.7)$ \\
\hline Corporate Image & 0.81940 & 0.90073 & Aesthetics & 0.75240 & 0.85851 \\
User Image & 0.84375 & 0.91525 & Preceived Quality & 0.68088 & 0.81008 \\
Product Image & 0.65359 & 0.84957 & Service Ability & 0.67508 & 0.86169 \\
Performance & 0.74649 & 0.85477 & Warranty & 0.78938 & 0.91828 \\
Features & 0.72106 & 0.83772 & Application Assistance & 0.74159 & 0.85063 \\
Conformance & 1.00000 & 1.00000 & Customer Service & 0.87648 & 0.93418 \\
Realibility & 0.81471 & 0.89788 & Repurchase Decision & 0.70323 & 0.87663 \\
Durability & 0.76188 & 0.86474 & & & \\
\hline
\end{tabular}
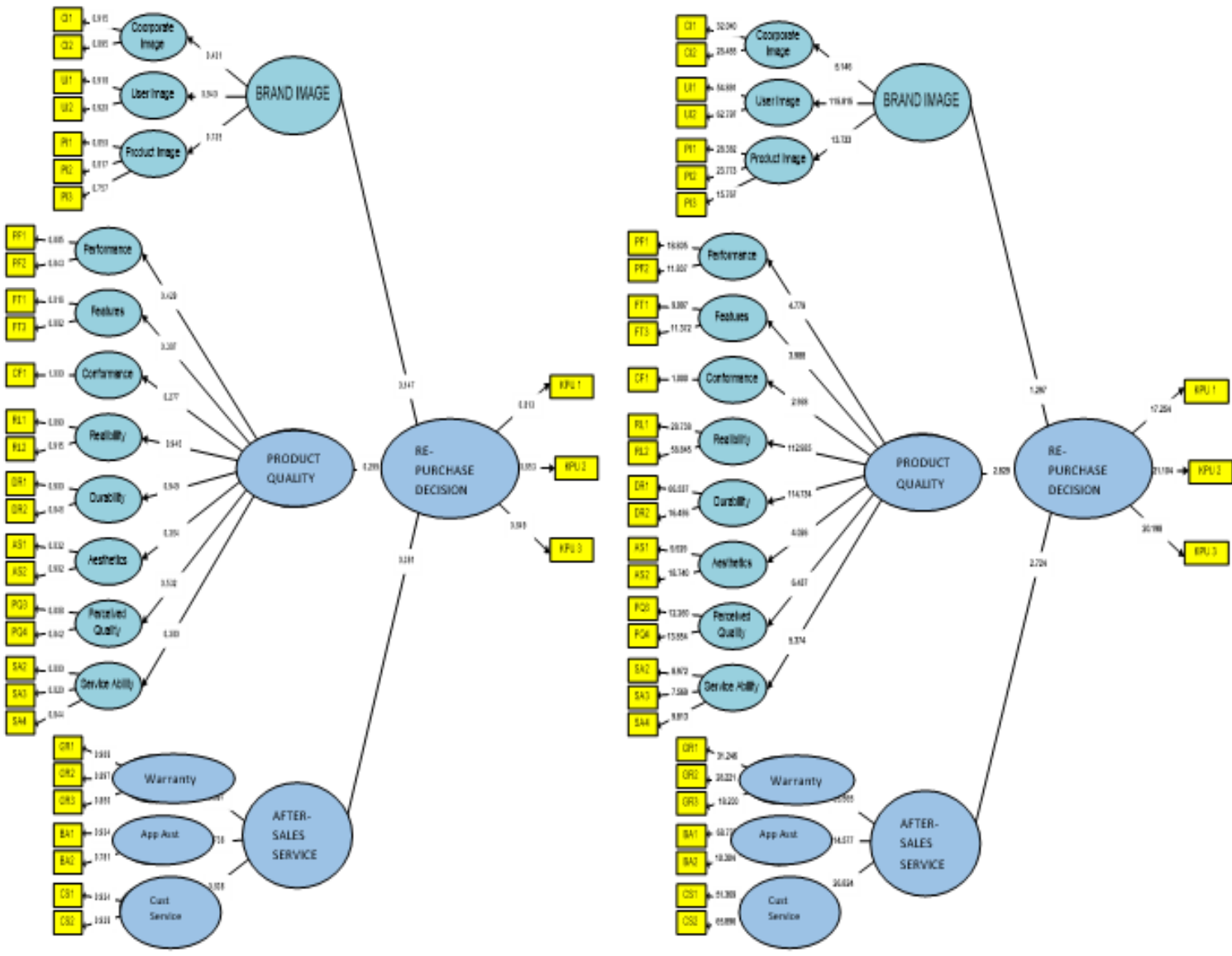

Figure 3 - Results of loading factor (left) and t-count (right) in the analysis of the SEM-PLS model

The structural model (inner model) describes the hypothesis that has been built in this study which will then be tested against the hypothesis. The results of the SEM-PLS model in this study can be seen in Figure 3. Simamora (2005) states that the hypothesis is a statement which at the time of disclosure is unknown, but allows it to be tested in empirical reality. Evaluation of Goodness of fit on the inner model can be measured using R-square dependent latent variables and using $Q$-square predictive relevance for structural models 
(Latan and Ghozali 2012). Q2 is used to measure how well the observation value generated by the Q-square model must be greater than zero $(>0)$, which indicates that the model has a good predictive model ability (Hair et al. 2010). The results obtained in this study using the PLS method and using software support SmartPLS M2.0.

The R-square result obtained is 0.47175 . This gives the meaning that the model of this study is the decision to repurchase Samsung smartphones can be explained by independent variables (brand image, product quality and after-sales service) of $47.2 \%$ and the remaining $52.8 \%$ explained by other variables outside of the model studied. The acquisition of the Rsquare value is then entered into the $\mathrm{Q}$-square equation to determine the magnitude of the prediction model that can be done. Based on the calculation results obtained by the Qsquare value, amounting to $0.222784(0.223)$.

The hypothesis test is used to test the effect of partially exogenous variables $(X)$ on endogenous variables $(\mathrm{Y})$ by looking at the t-values in each path. The inner weight coefficient value of the structural model is said to be significant or the hypothesis is declared significant and has a direct effect, if the value of the path coefficient obtained is positive and the t-count value is greater than the t-table value (1.96) with a $95 \%$ confidence level.

Table 5 - Results of hypothesis test

\begin{tabular}{lccc}
\hline \multicolumn{1}{c}{ Hypotesis } & Coefficient inner weight & [t-hit] & Conclusion \\
\hline Brand image $\rightarrow$ Repurchase decision $^{(+)}$ & 0.147 & 1.296 & H1 denied \\
Quality product $\rightarrow$ Repurchase decision $^{(+)}$ & 0.299 & $2.829^{*}$ & H2 accepted \\
After-sales service $\rightarrow$ Repurchase decision $^{(+)}$ & 0.391 & $2.724^{*}$ & H3 accepted \\
\hline
\end{tabular}

$\left.{ }^{*}\right)$ shows $t$-value $>1.96$ or significant. ${ }^{(+)}$shows a positive relationship.

Based on the results of testing the hypothesis, it can be seen that the brand image has a positive coefficient value but the t-count value is smaller than t-table (1.96), which means that it is not significant. This indicates that there is no influence between the brand image to make decision to buy Samsung smartphones. This result is in line with the research conducted by Arista and Astuti (2011), Bloemer et al. (1998) which state that the brand does not have a direct positive effect on consumer purchasing decisions and loyalty, and Hanzaee and Farsani (2011) who obtained the results of the study did not have an indirect relationship between brand image of consumer purchasing decisions, even through satisfaction.

Samsung smartphone consumers have more confidence in the reliability and durability of these products, believe the product quality and believe the quality of after-sales services that they provide, which is like warranty. It is known from the respondents' answers to the question of product quality and after-sales service, so that it can be concluded that the brand image indicator, corporate image, user image and product image is not a guarantee to brand image for repurchase Samsung smartphones.

Based on the results of testing the hypothesis, it can be seen that the brand image has a positive coefficient value but the t-count value is smaller than t-table (1.96), which means that it is not significant. This indicates that there is no influence between the brand image of the decision to buy Samsung smartphones. This result is in line with the research conducted by Arista and Astuti (2011), Bloemer et al. (1998) which states that the brand does not have a direct positive effect on consumer purchasing decisions and loyalty, and Hanzaee and Farsani (2011) who obtained the results of the study did not have an indirect relationship between brand image of consumer purchasing decisions, even through satisfaction.

Samsung smartphone consumers have more confidence in the reliability and durability of these products, believe in product quality and believe in the quality of after-sales services that they provide, which is like warranty. It is known from the respondents' answers to the question of product quality and after-sales service, so that it can be concluded that the brand image indicator, corporate image, user image and product image is not a guarantee to brand image for repurchase Samsung smartphones.

The results of testing the hypothesis related to the quality of the product to srepurchase decision obtain significant results. This indicates that product quality has an effect on repurchase decisions. This research is in line with research conducted by Chowdhury (2017) 
which states that product quality influences repurchase decisions and there are eight dimensions of product quality (serviceability, conformance, aesthetic, perceived quality, reliability, features, performance and durability) that are considered by customers before or after choosing a brand from a particular smartphone. Good product quality, easier to create impressions and interests with consumers, which consumers will feel suitable with the model and size/features provided by the brand and tend to be lazy to find or replace with other brands that do not necessarily provide models or features that according to consumer tastes (Devi and Sugiharto 2017). This causes the better quality of the product offered, the greater the percentage of consumers to make a decision to repurchase the product (smartphone) from the brand.

\section{MANAGERIAL IMPLICATIONS}

Based on the research and analysis that has been done using SEM-PLS to analyze the effect of brand image, product quality and after-sales service on Samsung smartphone repurchase decision, managerial implications are obtained as follows:

Table 6 - Managerial implications

\begin{tabular}{ll}
\hline \multicolumn{1}{c}{ Variables } & \multicolumn{1}{c}{ Managerial Implications } \\
\hline Product & Quality aspects of product durability by maintaining and improving the quality of long-lasting \\
Quality & $\begin{array}{l}\text { batteries and the durability of Samsung smartphones. } \\
\text { Product reliability aspects by maintaining and improving the quality of the hardware and software } \\
\text { sector of Samsung smartphones. }\end{array}$ \\
& $\begin{array}{l}\text { Improve product quality (smartphone) by paying attention to the characteristics and } \\
\text { specifications of users with the help of appropriate new technology. }\end{array}$ \\
After-Sales & Samsung companies pay special attention to smartphone users in their responsive reactions and \\
Service & easy access to services in making warranty claims on the products they have. \\
& $\begin{array}{l}\text { Improve after-sales service of Samsung smartphones by improving service center services in } \\
\text { every authorized Samsung store and serving all the needs of users (consumers) with excellence. }\end{array}$ \\
\hline
\end{tabular}

\section{CONCLUSION AND SUGGESTIONS}

The conclusion of this study is that Samsung consumers or smartphone users are in the middle class social level that is active in the use of mobile phones in everyday life. Product quality and after-sales service influence repurchase decision, while brand image has no effect on Samsung smartphone repurchase decision. Based on the results of the study, the managerial implications for Samsung as a producer are to maintain the quality of durability (product life span, product durability) and reliability (related to the product functioning well in a period of time and under certain conditions) Samsung smartphone products and giving special attention to smartphone users in easy access make warranty claims about the products they have.

Based on the results of the analysis and conclusions outlined above, the suggestions that the research proposes are in the form of further research to develop new research models using different variables from this study or can also analyze the relationship between exogenous variables in this study. This research is also limited to the perceptions of consumers who have carried out after-sales services on Samsung smartpone products, so that further research can be carried out to analyze the consumers of Samsung smartphones as a whole or can be for new prospective customers.

\section{REFERENCES}

1. Aaker DA, Biel AL. 1993, Brand Equity \& Advertising: Advertising's Role in Building Strong Brands. New Jersey: Lawrence Erlbaum Associates, Inc

2. Arista ED, Astuti SRT. 2011. Analisis pengaruh iklan, kepercayaan merek and citra merek terhadap minat beli konsumen. Jurnal Aset. 13(1): 37-45. 
3. Ain N, Ratnasari RT. 2015. Pengaruh citra merek melalui sikap konsumen terhadap niat beli ulang pada produk busana muslim zoya di Surabaya. Jurnal Ekonomi Syariah Teori and Terapan. 2(7): 553-569

4. Assael H. 1998. Customer Behavior and Marketing Actions. ED ke-2. New York (US): International Thomson Publishing.

5. Bakator M, Petrović N. 2016. Correlation between Marketing Strategy, Product Quality and Promotion on the Mobile Devices Market in Serbia. Journal of Engineering Management and Competitiveness. 6(2): 67-74.

6. Bayhaqi Y. 2006. Analisis Pengaruh Kualitas Layanan and Keunggulan Produk terhadap Kepuasan Pelanggan and Dampaknya Pada Minat Membeli Ulang (Studi kasus: Auto Bridal Semarang) [thesis]. Semarang (ID): Universitas Diponegoro

7. Bloemer J, de Ruyter K, Peeters F. 1998. The relationship between store image, store satisfaction and store loyalty. European Journal of Marketing. 32(5/6): 499-513.

8. Boyd HW, Walker OC, Larreche JC. 2000. Manajemen Pemasaran Suatu Pendekatan Strategis dengan Orientasi Global. Translated by Imam Nurmawan. Ed ke-2. Jakarta (ID): Erlangga

9. Chen HS, Hsieh T. 2011. A Study of Antecedents of Customer Repurchase Behaviors in Chain Store Supermarkets. The Journal of International Management Studies. 6(3): .1-11

10. Chowdhury SR. 2017. Measuring the Relationship between Product Quality Dimensions \& Repurchase Intention of Smart Phone: A Case study on Chittagong City. International Journal of Scientific \& Engineering Research. 8(2): 1031-1040

11. Devaraj S, Matta KF, Edward C. 2001. Product and service quality: the antrcedents of customer loyality in the automotive industry. Production and Operations Management: Winter. 10(4): 424

12. Devi S, Sugiharto S. 2017. Pengaruh Product Quality and Retail Service Quality terhadap Repurchase Intention dengan Customer Familiarity sebagai Variabel Intervening pada Store Zara di Surabaya. Jurnal Strategi Pemasaran. 4(2): 1-8.

13. Dewi DR, Magdalena MM, Dhiana P. 2015. Pengaruh Word of Mouth, Tingkat Pendapatan and Kualitas Produk terhadap Keputusan Pembelian yang Berdampak pada Minat Beli Ulang Konsumen (Studi kasus pada produk Bandeng Juwana Elrina Semarang). Journal of Management. 1(1): 1-19

14. Diyah SM, Arifin Z, Yaningwati F. 2013. Pengaruh Pelayanan Purna Jual Terhadap Keputusan Pembelian. Jurnal Administrasi Bisnis. 3(2): 1-9.

15. Engel JF, Blackwell RD, miniard PW. 1995. Perilaku Konsumen. Jilis 2. Ed ke-6. Budiyanto FX, translator. Jakarta (ID): Binarupa Aksara. Translated from: Customer Behavior.

16. Evans JR, Laskin RL. 1994. The Relationship Marketing Process: A Conceptualization and Application. Industrial Marketing Management. 23(5): 439-454.

17. Faradiba, Astuti SRT. 2013. Analisis Pengaruh Kualitas Produk, Harga, Lokasi and Kualitas Pelayanan Terhadap Minat Beli Ulang Konsumen. Diponegoro Journal of Management. 2(3): 1-11

18. Garvin DA. 1987. Competing on the Eight Dimensions of Quality. Harvard Business Review. 65(6):101-109.

19. Hadi MI. 2015. Pengaruh Ekuitas Merek and Kepuasan Pelanggan Terhadap Loyalitas Smartphone Samsung di UMY. Prosiding Interdisciplinary Postgraduate Student Conference. [Working paper]. 277-286

20. Hair Jr JF, Black WC, Babin BJ, Anderson RE, Tatham RL. 2006. Multivariate Data Analysis. Ed. Ke-6. New Jersey (US): Prentice Hall.

21. . 2010. Multivariate Data Analysis. Ed. Ke-7. New Jersey (US): Pearson Education.

22. Hanzaee KH, Farsani FT. 2011. The Effects of Brand Image and Perceived Public Relation on Customer Loyalty. World Applied Sciences Journal. 13(2): 277-286.

23. Huang Y, Lee K, Chan W. 2011. An Empirical Study of Consumer's Repurchase Intention of Tablet PC. International Conference on Computer Science \& Education. 1(1): 166-171. 
24. Iriani SS, Tunjungsari RH. 2015. Pengaruh Brand Extension, Kualitas Produk, and Layanan Purna Jual Terhadap Keputusan Pembelian Asus Smartphone. Jurnal Riset Ekonomi and Manajemen. 15(2): 212-232.

25. Isaac L, Adeyemo SA, Ogunleye PO. 2013. Impact of After Sales Service on Consumer Satisfaction and Retention. A Study of LG Electronics in Ibadan, Nigeria. Journal of Business and Management. 11(4): 54-58

26. Iskandar D. 2015. Pengarug Service, Product Quality and Perceived Value terhadap Kepuasan and Repurchase Konsumen Kedai Sop Buah Durian Lodaya di Bogor [thesis]. Bogor (ID): Institut Pertanian Bogor.

27. Isyanto P, Eman, Herligiani. 2012. Pengaruh Kualitas Produk Terhadap Keputusan Pembelian Handphone Blackberry Pada Mahasiswa Ekonomi Universitas Singaperbangsa Karawang. Jurnal Manajemen 9(4): 854-862.

28. Jogiyanto, Willy A. 2009. Konsep and Aplikasi PLS (Partial Least Square) untuk Penelitian. Yogyakarta (ID): Andi Offset

29. Junaidi. 2016. Ada Kejanggalan, Layanan Service Centre Ponseel Mengecewakan. Tersedia pada: https://m.detik.com/news/suara-pembaca/d-3374817/ada-kejanggalanlayanan-service-center-ponsel-mengecewaka

30. Keller KL. 2008. Strategic Brand Management Building, Measuring and Managing Brand Equity. Ed ke-3. New Jersey (US): Pearson.

31. Kotler P. 2009. Manajemen Pemasaran. Jakarta (ID): Erlangga

32. Kotler $P$, Armstrong. 2008. Prinsip-Prinsip Pemasaran. Jakarta (ID): Erlangga.

33. Kriswandari S. 2010. Influence of Services on Consumer Satisfaction at PT. Tunas Dwipa Matra in Lampung. Jurnal Manajemen and Bisnis. 1(1): 50-67.

34. Kurniawan I, Santoso SB, Dwiyanto BM. 2010. Analisis Faktor-Faktor yang Mempengaruhi Minat Beli Ulang Produk serta Dampaknya terhadap Loyalitas Pelanggan. Jurnal Studi Manajemen \& Organisasi, 4(2): 27-42

35. Latan H, Ghozali I. 2012. Partial Least Squares Konsep, Teknik and Aplikasi SmartPLS 2.0 M3 untuk Penelitian Empiris. Semarang (ID): Badan Penerbit Universitas Diponegoro.

36. Lin CC, Wu HY, Chang YF. 2011. The critical factors impact on online customer satisfaction. Procedia Computer Sience. 3(2011): 276-281.

37. Lin NH, Lin BS. 2007. The Effect of Brand Image and Product Knowledge on Purchase Intention Moderated By Price Discount. Journal of International Management Studies. 121-132.

38. Meutia R. 2017. Pengaruh Brand Extension, Kualitas Produk and Layanan Purna Jual terhadap Keputusan Pembelian Asus Smartphone di Kota Kuala Simpang. Jurnal Manajemen and Keuangan. 6(1): 700-709

39. Paramananda N, Sukaatmadja IPG. 2018. The Impact of Price Perception and Brand Image on Customer Satisfaction and Repurchase Intention. International Journal of Economics, Commerce and Management. 6(10): 212-224

40. Rangkuti F. 2004. The Power of Brand. Jakarta (ID): PT Gramedia Pustaka Utama

41. Ranjbarian B, Sanayei A, Kaboli MR, Hadadian A. 2012. An Analysis of Brand Image, Perceived Quality, Customer Satisfaction and Re-purchase Intention in Iranian Department Stores. International Journal of Business and Management. 7(6): 40-48.

42. Roberts PW, Dowling GR. 2002. Corporate Reputation and Sustained Superior Financial Performance. Strategic Management Journal. 23(1): 1077-1093.

43. Ruusen FP, Adolfina, Ogi I. 2014. Kualitas Pelayanan, Promosi and After Sales Service Pengaruhnya terhadap Kepuasan Konsumen Sepeda Motor Honda PT. Nusantara Surya Sakti di Amurang. Jurnal Riset Ekonomi, Manajemen, Bisnis and Akutansi. 2(4): 16031613.

44. Saidin ZH, Mokhtar SSM, Saad R, Yusoff RZ. 2015. Automotive After-Sales Service Quality and Relationship Quality in Malaysian National Car Makers. International Academic Research Journal of Business and Technology. 1(2): 71-78.

45. Schiffman LG, Kanuk LL. 1997. Consumer Behaviour. Ed ke-6. Prentice Hall. New Jersey.

46. Setiadi NJ. 2003. Perilaku Konsumen: Konsep and Implikasi untuk Strategi and 
Penelitian Pemasaran. Jakarta (ID): Kencana.

47. Simamora B. 2005. Analisis Multivariat Pemasaran. Jakarta (ID): PT Gramedia Pustaka Utama.

48. . 2008. Panduan Riset Konsumen. Cetakan ketiga. Jakarta (ID): PT. Gramedia Pustaka Utama.

49. Singh M. 2013. Product Quality for Competitive Advantage in Marketing.International Journal of Business and Management Invention 2(6): 05-08.

50. Sugiarto, Dergibson S, Lasmono TS, Deny SO. 2003. Teknik Sampling. Cetakan ke-2. Jakarta (ID): PT Gramedia Pustaka Utama.

51. Sugiyono. 2012. Metode Penelitian Bisnis. Bandung (ID): Alfabeta

52. Sumarwan U, Daryanto A, Achsani NA, Fahmi I, Nuryanto N, Suhendi, Samputra PL, Sijabat FDV, Tobing A, Kristiadi A. 2015. Metode Riset Bisnis and Konsumen. Bogor (ID): IPB Press.

53. Sun SY, Chen LS, Huang HC. 2014. Social Cognition and The Effect of Product Quality on Online Repurchase Intention.

54. Sundalangi M, Mandey SL, Jorie RJ. 2014. Kualitas Produk, Daya Tarik Iklan and Potongan Harga terhadap Minat Beli Konsumen Pada Pizza Hut Manado. Jurnal Riset Ekonomi Manajemen Bisnis and Akuntansi, 2(1): 313-324

55. Susanto H. 2016. The Effect of Brand Image, Product Quality and Price toward Purchase Decision (Empirical Study on Consumer Cv. Rown Division in Surakarta) [tesis]. Surakarta (ID): Universitas Muhammadiyah Surakarta.

56. Tarmizi A. 2016. Pengaruh pelayanan purna jual terhadap keputusan pembelian konsumen pada PT Jaya Indah Motor Cabang Jambi. Jurnal IImiah Universitas Batanghari Jambi. 16(3): 115-121

57. Tjiptono F. 2008. Strategi Pemasaran. Ed ke-3. Yogyakarta (ID): Penerbit Andi.

58. Tjiptono F, Chandra G. 2012. Pemasaran Strategik. Yogyakarta (ID): Penerbit Andi.

59. Wijaya HR, Astuti SRT. 2018. The Effect of Trust and Brand Image to Repurchase Intention in Online Shopping. International Conference on Economics, Business and Economic Education 2018. [Working paper] KnE Social Sciences: 915-928.

60. Wijaya Y. 2019. Pengaruh After-Sales Service terhadap Repurchase Intention melalui Customer Satisfaction sebagai Variabel Intervening di PT Damai Sejahtera Abadi (Ufo Elektronika) Surabaya. AGORA. 7(1): 1-7

61. Wulansari A. 2013. Pengaruh Brand Trust and Perceived Quality terhadap Keputusan Pembelian Ulang Produk Sari Roti (Studi pada konsumen di Perumahan Gresik Kota Baru, Manyar Gresik). Jurnal IImu Manajemen. 1(2): 388-401.

62. Yulisetiarini D, Subagio A, Paramu H, Irawan B. 2017. Customer Repurchase Intention and Satisfaction in Online Shopping. International Business Management. 11(1): 215221. 